\title{
Concomitant Presence of Hydatid Cyst and Colorectal Liver Metastasis
}

\author{
Kist Hidatikve Kolorektal Karaciğer Metastazının Eşzamanlı Varlı̆̆ \\ (1) Jurica Zedelj ${ }^{1}$, (1) Igor Petrovic ${ }^{1}$, (1) Goran Pavlek ${ }^{1}$, (1) Trpimir Moric ${ }^{2}$, (1) Marijan Romic ${ }^{3}$, \\ (1) Hrvoje Silovski ${ }^{1}$, (1) Renata Romic ${ }^{4}$, (1) Ivan Romic ${ }^{1}$ \\ ${ }^{1}$ University Hospital Centre Zagreb Faculty of Medicine, Department of Surgery, Zagreb, Croatia \\ ${ }^{2}$ University Hospital Centre, Department of Gastroenterology, Zagreb, Croatia \\ ${ }^{3}$ University Hospital Sestre Milosrdnice, Department of Surgery, Zagreb, Croatia \\ ${ }^{4}$ Dom Zdravlja Center, Zagreb, Croatia
}

Cite this article as: Zedelj J, Petrovic I, Pavlek G, Moric T, Romic M, Silovski H, Romic R, Romic I. Concomitant Presence of

Hydatid Cyst and Colorectal Liver Metastasis. Turkiye Parazitol Derg 2021;45(2):146-148.

\begin{abstract}
A 65-year-old man, with signs of acute colon obstruction, was diagnosed with rectal tumour and liver hydatid cyst. Additionally, a focal liver lesion in segment 1 was detected. Moreover, physical examination revealed hepatomegaly and abdominal distension. Thus, rectal resection and small liver lesion biopsy was performed. Serological and pathohistological analyses showed concomitant presence of hydatid cyst and colorectal metastasis in the liver. Hence, the cyst was treated with anthelmintic therapy, and patient lived another year after the diagnosis. To the best of our knowledge, cases of concomitant hydatid cyst and colorectal liver metastasis has never been reported; thus, this article addresses a unique case of coexistence between these two serious liver diseases.
\end{abstract}

Keywords: Hydatid cyst, metastasis, liver

Öz

Akut kolon tıkanıklığı bulguları olan 65 yaşında erkek hastada rektal tümör ve karaciğer kist hidatiği ve segment 1'de fokal karaciğer lezyonu saptandı. Hastanın fizik muayenesinde hepatomegali ve abdominal distansiyon mevcuttu. Rektal rezeksiyonu ve daha küçük olan lezyonun karaciğer biyopsisi yapıld. Serolojik ve histopatolojik analizde karaciğerde kist hidatik ve kolorektal metastaz varlığı eşlik etti. Kist antemintik tedavi ile tedavi edildi ve hasta tanıdan 1 yıl sonra halen yaşamaktaydı. Bildiğimiz kadarıyla bugüne kadar eşzamanlı kist hidatik ve kolorektal karaciğer metastazı olgusu bildirilmemiştir. Bu nedenle mevcut makale bu iki ciddi karaciğer hastalığının bir arada var olduğu benzersiz bir olguyu ele almaktadır.

Anahtar Kelimeler: Kist hidatik, metastaz, karaciğer

\section{INTRODUCTION}

Hydatid cyst is a parasitic endemic zoonosis caused by the tapeworm E. granulosus that is mostly found in the small intestine of dogs while sheep are intermediate hosts. After ingestion, usually through contaminated water or food, the eggs hatch in the intestine, penetrate the intestinal wall, and reach the liver via portal vein. Other target organs are most commonly lung, brain and heart. Serologic tests and computerized tomography (CT) are required to confirm the diagnosis (1). CT scan is highly specific and it can provide information on the location, size and structure of the cyst. Surgical removal of cyst is the mainstay of treatment, but percutaneous treatment or medical therapy with albendazole are alternative method in selected patients (2). There are sporadic reports on hepatocellular carcinoma associated with synchronous hydatic cyst, but to the best of our knowledge, no case of concomitant colorectal liver metastasis and hydatid cyst has been reported thus far in the literature $(3,4)$. The present case suggests that multiple cystic liver lesions should be evaluated meticulously in order to prevent misdiagnosis. Written informed consent was obtained from the patient. 


\section{CASE REPORT}

A 65-year-old male patient was admitted to our hospital complaining of obstipation, nausea, abdominal pain and distension. He reported weight loss $(15 \mathrm{~kg})$, blood in stool and intermittent fevers over a period of 3 months. Prior diseases included arterial hypertension and chronic obstructive pulmonary disease. He lived in a rural area, 20 kilometers far from the Adriatic coast (northernmost arm of the Mediterranean). He and worked on a sheep farm for the last 5 years and was in daily contact with domestic cats and dogs. The patient denied recent travel or known infectious diseases. Clinical examination revealed hepatomegaly and abdominal distension and laboratory findings were as follows: hemoglobin $76 \mathrm{~g} / \mathrm{dL}$, white blood count 16.7/ $\mathrm{mm}^{3}$ with $82 \%$ of neutrophils, C-reactive protein $90.2 \mathrm{mg} / \mathrm{L}$, total bilirubin $3.57 \mathrm{mg} / \mathrm{dL}$, aspartate aminotransferase $122 \mathrm{U} / \mathrm{I}$ and alanine aminotransferase $87 \mathrm{U} / \mathrm{I}$. Abdominal computerized tomography showed a large cystic lesion of the liver measuring $21 \times 15 \times 17 \mathrm{~cm}$ which included membranes (snake/serpent sign) located in the right lobe of the liver (Figure 1A, white arrow). There was a small area of hypodense fluid within the described cyst (Figure 1B, red arrow). Another hypodense oval liver lesion of open etiology measuring $2.8 \mathrm{~cm}$ was found in first liver segment (Figure 2 and Figure $3 \mathrm{~A}-\mathrm{C}$, blue arrow). Differential diagnosis included daughter cyst or liver tumor, although, there were no

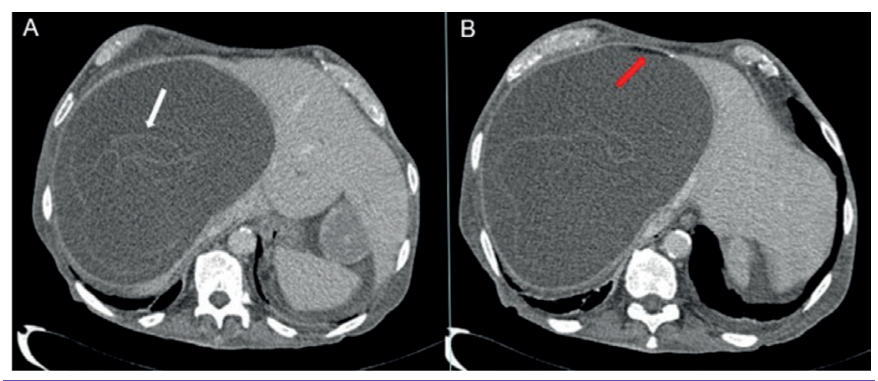

Figure 1. Axial CT projections showing: A) Large hydatid cyst occupying right liver lobe with multiple floating membranes inside the lesion (white arrow), B) Intracystic fluid level (red arrow)

CT: Computerized tomography

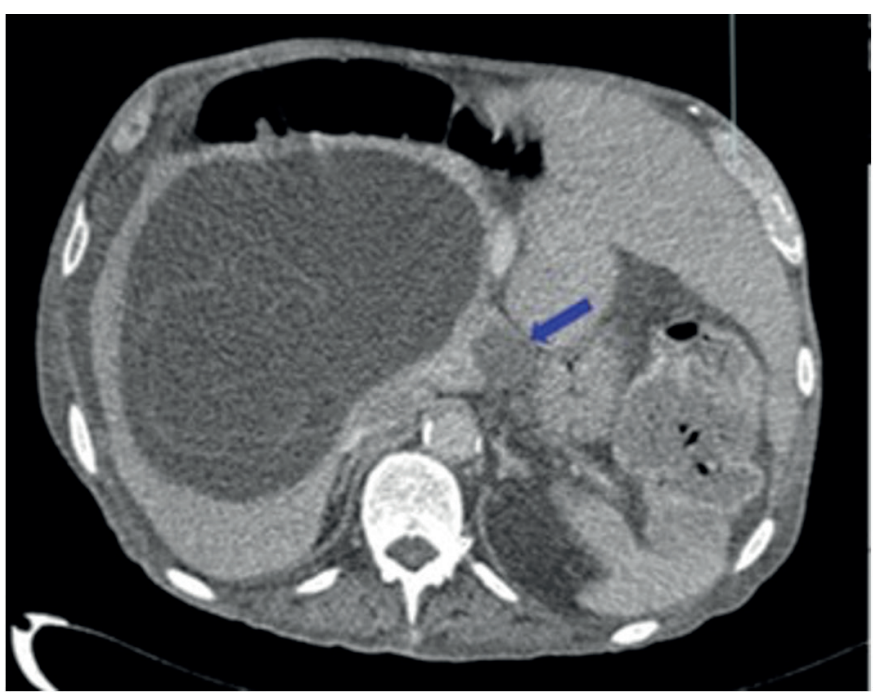

Figure 2. Axial CT projections showing hypodense liver lesion in the first segment

CT: Computerized tomography signs of membranes as seen within the larger cyst, so the tumor was highly suspicious of being a metastasis of primary digestive tumor. Considering this, colonoscopy was performed that verified obstructive tumor at the upper rectum.

Urgent surgical procedure was performed and included rectosigmoid resection with colostomy, and biopsy of smaller liver lesion. Hydatid cyst was not managed due to high operative risk.

The postoperative course proceeded without any complications. Pathohistological analysis confirmed primary adenocarcinoma (T4,N1,M1,G3) with liver metastasis and Echinococcus indirect hemagglutination test was positive at a titre of $1 / 1,280$.

The patient was further treated with chemotherapy antiechinococcal treatment with albendazole. One year after surgery, patient is still alive, and has no symptoms related to liver lesions.

\section{DISCUSSION}

Cystic echinococcosis is zoonotic parasitic disease that may have serious consequences in untreated cases. It still remains a significant health problem in endemic regions and sheepraising agricultural areas such as Mediterranean, South-eastern Europe, Middle East, South America and Oceania (5). In modern health systems with advanced imaging techniques, the diagnosis of liver echinococcosis is usually straight-forward, but more complex aspects of hydatid cyst may also mimic solid hepatic masses (6). Study from Mor et al. (7) suggests that hydatid cyst is still an important health problem in specific areas with up to $40.0 \%$ sero-positivity rate and it found correlation between low socioeconomic level and hydatid cyst prevalence. Therefore, authors conclude that emphasizing public health trainings and improvement of hygiene awareness may be effective in fighting against this disease (7).

Differential imaging considerations in focal liver lesions include a variety of disorders: hemangioma, hepatic cysts, tumors, focal nodular hyperplasia, hepatic adenoma, multifocal fatty infiltration, biliary hamartomas, liver abscesses or non-Hodgkin lymphoma (8).

Furthermore, hydatid cysts with synchronous non-infectious liver lesions may pose even greater diagnostic and therapeutic challenge. Firstly, synchronous liver lesions may be misinterpreted as additional hydatid or daughter cyst and in case of malignant disease, it may delay appropriate treatment. Secondly, multiple

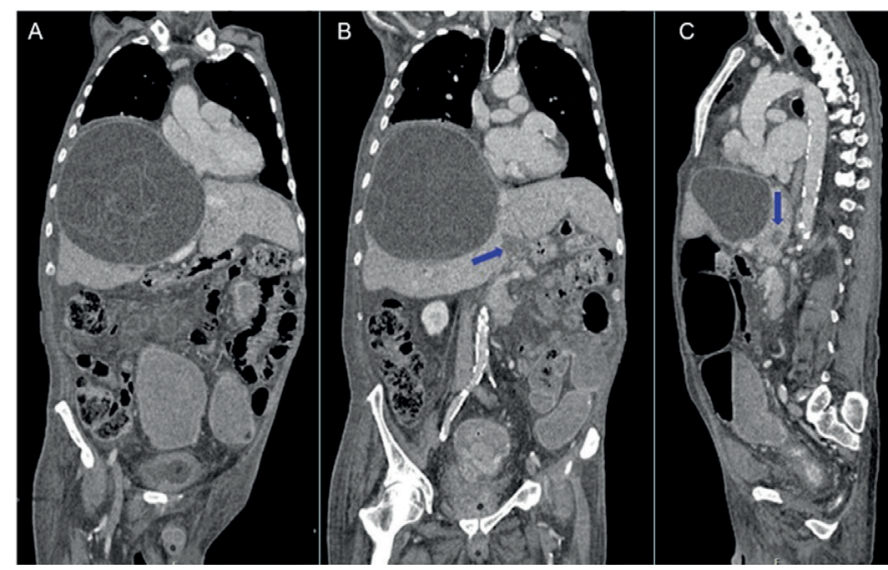

Figure 3. Axial (A and B) and sagittal (C) CT projections showing hydatid cyst and tumor (blue arrow) CT: Computerized tomography 
hydatid cysts may mimic other liver lesions which requires additional imaging methods to rule out liver tumors. Therefore, if more cystic lesions are discovered in a patient with highly suspected hydatid cyst, clinicians should be aware of the possibility that all cystic lesions are not of the same origin $(7,8)$.

Consequently, it is important to look for daughter vesicles or membranes within all lesions that may help in differential diagnosis. CT usually shows internal septa, floating membranes or daughter vesicles and sometimes are cysts surrounded by calcified ringlike wall and cysts appear as a well-defined waterattenuation mass. Detachment of the laminated membranes from the pericyst are visualized as linear areas of increased attenuation [so called (snake/serpent sign)] and may be sign of hydatid cyst damage, degeneration or contained rupture. Intracystic air-fluid level is a possible sign of super-infection. At CT, a use of intravenous contrast is important in differentiation of hydatid from simple liver cysts and tumors. Liver metastases are typically hypoattenuating and hypodense on unenhanced CT, enhancing less than surrounding liver after contrast application (8).

Percutaneous aspiration-injection-reaspiration is a relatively novel method of hydatid cyst treatment and it shows high success rate and low rates of recurrence and complications so it should be considered an important alternative to surgery (9).

The impact of hydatid cyst on liver tumor occurrence or progression is out of scope of this paper and some articles described such relation, mostly for hepatocellular carcinomas, but we hypothesize that such large cysts may have protective role by suppressing development of multiple colorectal liver metastases. This may be explained by reduced liver parenchyma or antitumoral effect of the cyst. In addition, hydatid cyst symptoms may be a reason of earlier patient presentation. However, whether echinococcal infection is beneficial in patients with malignant liver tumors, still remains unclear and future studies on larger number of patients are required to draw reliable scientific conclusions (10-12).

\section{CONCLUSION}

Our article suggests that echinococcosis is still present in southeastern Europe and should be considered in the differential diagnosis of abdominal pain with intermittent fevers. It must also be emphasized that synchronous liver masses should be investigated in order to rule out possible concomitant malignant disease, which will direct further treatment approach.

\section{* Ethics}

Informed Consent: Written informed consent was obtained from the patient.
Peer-review: Internally peer-reviewed.

\section{** Authorship Contributions}

Surgical and Medical Practices: J.Z., Concept: J.Z., G.P., R.R., I.R., Design: H.S., T.M., Data Collection or Processing: J.Z., Analysis or Interpretation: H.S., I.R., Literature Search: M.R., T.M., Writing: J.Z., I.P., R.R., I.R.

Conflict of Interest: No conflict of interest was declared by the authors.

Financial Disclosure: The authors declared that this study received no financial support.

\section{REFERENCES}

1. Almulhim AM, John S. Echinococcus Granulosus. 2020 Aug 10. In: StatPearls [Internet]. Treasure Island (FL): StatPearls Publ.

2. Buttenschoen K, Carli Buttenschoen D. Echinococcus granulosus infection: the challenge of surgical treatment. Langenbecks Arch Surg 2003; 388: 218-30.

3. Karadas S, Dulger AC, Gonullu H, Bulut G, Beyazal M. Coexistence of hepatocelluler carcinoma and cyst hydatid disease of the liver. J Pak Med Assoc 2014; 64: 1075-7.

4. Romic B, Romic I, Petrovic I, Romic M, Romic R, Romic M, et al. A Synchronous Occurrence of Hepatocellular Carcinoma and Echinoccocal Liver Cyst - Can Parasite Promote Carcinogenesis? Literature Review and Classification Proposal. Chirurgia (Bucur) 2016; 111: 297-303.

5. Junghanss T, da Silva AM, Horton J, Chiodini PL, Brunetti E. Clinical management of cystic echinococcosis: state of the art, problems, and perspectives. Am J Trop Med Hyg 2008; 79: 301-11.

6. Bayrak M, Altıntas Y. Current approaches in the surgical treatment of liver hydatid disease: single center experience. BMC Surg 2019; 19: 95.

7. Mor N, Diken Allahverdi T, Allahverdi E, Tekdoğan ÜY. Retrospective Evaluation of Patients Diagnosed with Cystic Echinococcosis at Kafkas University Faculty of Medicine's Surgical Outpatients Unit. Turkiye Parazitol Derg 2018; 42: 196-201.

8. Amin MU, Mahmood R, Shafique M, Khan MS, Bilal A, Siddiqi HA. Pictorial review: Imaging features of unusual patterns and complications of hydatid disease. J Radiol Case Rep 2009; 3: 1-24.

9. Kasırga HE, Appak YC. Hepatik kistik ekinokokkozis: iki olgunun sunumu [Hepatic cystic echinococcosis: report of two cases]. Turkiye Parazitol Derg 2013; 37: 285-7.

10. Bakoyiannis A, Delis S, Triantopoulou C, Dervenis C. Rare cystic liver lesions: a diagnostic and managing challenge. World J Gastroenterol 2013; 19: 7603-19.

11. Gundogdu SB, Saylam B, Tez M. Cyst hydatid and cancer: the myth continues. Clin Chem Lab Med 2017; 55: 150-1.

12. Oikonomopoulou K, Yu H, Wang Z, Vasiliou SK, Brinc D, Christofi G, et al. Association between Echinococcus granulosus infection and cancer risk - a pilot study in Cyprus. Clin Chem Lab Med 2016; 54: 1955-61. 